\title{
Performance of Expanded Graphite as Anode Materials for High Power Li-ion Secondary Batteries
}

\author{
Do-Youn Park ${ }^{1}$, Yun-Soo Lim² and Myung-Soo Kim, ${ }^{3, \wedge}$ \\ ${ }^{1}$ Team of Battery R\&D, CM PARTNERR Co., Ltd., Seoul 136-179, Korea \\ ${ }^{2}$ Department of Material Science and Engineering, Myongji University, Gyeonggi-do 449-728, Korea \\ ${ }^{3}$ Department of Chemical Engineering, Myongji University, Gyeonggi-do 449-728, Korea \\ ^e-mail: myungkim@mju.ac.kr \\ (Received October 26, 2010; Accepted December 2, 2010)
}

\begin{abstract}
The various expanded graphites (EGs) was prepared and applied as anode material for high power Li-ion secondary battery (LIB). By changing the processing conditions of EG, a series of EG with different structure were produced, showing the changed electrochemical properties. The charge-discharge test showed that the initial reversible capacity of EG anodes prepared at the suitable conditions was over $400 \mathrm{mAh} / \mathrm{g}$ and the charge capacity at $5 \mathrm{C}$-rate was $83.2 \mathrm{mAh} / \mathrm{g}$. These values demonstrated the much improved electrochemical properties as compared with those for the graphite anode of $360 \mathrm{mAh} / \mathrm{g}$ and $19.4 \mathrm{mAh} / \mathrm{g}$, respectively, showing the possibility of EG anode materials for high power LIB.
\end{abstract}

Keywords : Expanded graphite, Lithium ion secondary battery, Anode materials, High power

\section{Introduction}

Carbon materials are the most actively used as anode materials for Li-ion secondary battery (LIB) due to their small surface change, stable structure, and favorable price. In order to apply LIB for electric vehicles (EV) and hybrid electric vehicles (HEV), they require not only high energy density but also high power density [1]. Therefore, the reversibility between charge and discharge of Li intercalation compounds used as the anode becomes of interest as an important factor for the battery mechanism [2,3].

Although the previous studies [4,5] of high capacity anode materials for LIB have focused on increasing amount of Li-ion intercalated, the studies [6-8] of high power anode materials emphasize the intercalation/deintercalation rate of Li-ion in the anode material structure. Graphite has a layer structure and the distance between the layers is about $3.35 \AA$. When the expanded graphite (EG) having wider layer distance is applied to the anode materials for LIB, it is be assumed that the intercalation/deintercalation of Li-ion can be done with ease as compared with the case of graphite.

The objective of this study is to prepare a series of EG with different structures using ammonium peroxodisulfate as an oxidizing agent and high purity of sulfuric acid as an intercalate, and to apply the EGs as an anode material for high power LIB. We tried to find the suitable processing conditions of EG in order to apply the prepared EG as the anode material for high power LIB.

\section{Experimental}

The flake type of natural graphite with well developed lamella structure (thickness: $10 \sim 15 \mu \mathrm{m}$ ) was used to make the EGs and the EGs were prepared by using ammonium peroxodisulfate $\left(\left(\mathrm{NH}_{4}\right)_{2} \mathrm{~S}_{2} \mathrm{O}_{8}\right.$, Junsei Chem Co., Ltd, assay 98.0\%) as an oxidizing agent and high purity of sulfuric acid $\left(\mathrm{H}_{2} \mathrm{SO}_{4}\right.$, J. T. Baker. Co., Ltd, assay $\left.96.6 \%\right)$ as intercalate. $20 \mathrm{~g}$ of natural graphite was added to a mixture of sulfuric acid $(600 \mathrm{~g})$ and calculated amount of ammonium peroxodisulfate in a double jacket reactor. The mixture was stirred at $98^{\circ} \mathrm{C}$ for $30 \mathrm{~min}$ and then dried in a oven at $80^{\circ} \mathrm{C}$ for $48 \mathrm{~h}$ after washing with distilled water until attaining neutralization. The dried samples were placed in a tube furnace reactor and heated to a desired temperature in the range of $800 \sim 1200^{\circ} \mathrm{C}$ maintaining 30 120 $\mathrm{min}$ at the temperature. The obtained EG samples were named as Ax-ty:Tz-tw, where Ax: the amount of ammonium peroxodisulfate (wt.\%), ty: the acid treatment time ( $\mathrm{min}), \mathrm{Tz}$ : the heat treatment temperature $\left({ }^{\circ} \mathrm{C}\right)$, and tw: the heat treatment time (min).

The anode active materials with particle sizes below $30 \mu \mathrm{m}$ were obtained by pulverizing the heat treated EG samples with a planetary mill and sieving at 400 mesh. The process variables such as the amount of oxidizing agent, the heat treatment temperature and heat treatment time were changed to find out the optimum manufacturing conditions of EG as the anode materials for LIB.

The crystallinity of various EG samples was analyzed by X-ray diffraction (XRD, Xpert-Pro, $\mathrm{CuKa}=1.54 \AA$ A, PANalytical) 
and the microstructure of various EGs was observed by scanning electron microscope (SEM, 3500N, Hitachi Science System Ltd., Japan).

The electrodes were prepared by mixing $93 \mathrm{wt} . \%$ of the anode active materials and $7 \mathrm{wt} . \%$ of polyvinylidene fluoride (PVDF) binder dissolved in 1-methyl-2-pyrrolidinone (NMP) with a homogenizer at rotation speeds of 4000 5000 rpm to form slurry. The mixed slurry was then coated on the copper foil by the Doctor Blade method and dried at $100^{\circ} \mathrm{C}$ in a vacuum oven for $24 \mathrm{~h}$ before being compressed by a roll press at $80^{\circ} \mathrm{C}$. The prepared anodes with $2.5 \times 2.5 \mathrm{~cm}$ size were kept in a glove box filled with argon where the contents of moisture and oxygen were controlled below $1 \mathrm{ppm}$. The prepared electrode was used as a working electrode and lithium foil adhered to copper mesh with $3.0 \times 3.0 \mathrm{~cm}$ size was used as a counter electrode. $1 \mathrm{M} \mathrm{LiPF}_{6}$ salt dissolved in a mixture of ethylenecarbonate (EC), ethylmethylcarbonate (EMC), and dimethylcarbonate (DMC) at 1:1:1 volume ratio was used as the electrolyte. The half cells were assembled in a glove box with argon atmosphere using polypropylene ( $\mathrm{PP}$; ; Celgard 2400 microporous membrane) separator to separate the cathode and anode.

The electrochemical properties of half cells were estimated by using a WBCS-3000 battery charge/discharge cycler (WonA Tech Co., Ltd.) at a constant temperature of $25^{\circ} \mathrm{C}$. The charge characteristics were measured by applying the constant current (CC) method at $0.2 \mathrm{C}$ for the first charge until reaching to $0.005 \mathrm{~V}$ and then changing to the constant voltage (CV) method for the successive charge by reducing the current until $2.5 \%$ of the initial current was attained. As for discharge, the $\mathrm{CC}$ method was applied at $0.2 \mathrm{C}$ until reaching to $2 \mathrm{~V}$. The current rates in the $\mathrm{CC}$ method were increased to 1 and $10 \mathrm{C}$ for the high rate charge-discharge characteristics. Here $1 \mathrm{C}$ meant a rate of current where the full charge or discharge for the given anode sample would take $1 \mathrm{~h}$ assuming $270 \mathrm{mAh} / \mathrm{g}$ of capacity.

\section{Results and Discussion}

Fig. 1 shows the SEM image of various EGs prepared using different amounts of oxidizing agent. The distance between the layers was increased with increasing the amount of oxidizing agent. As the result, the specific surface area

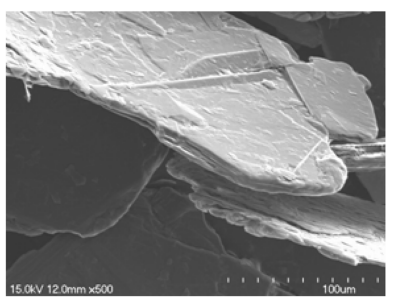

(a)

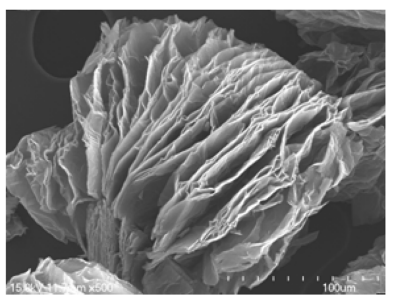

(c)

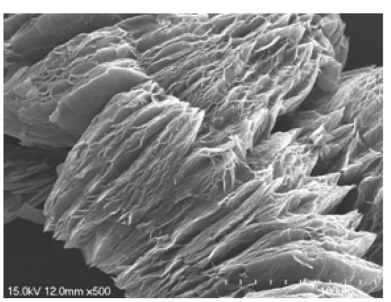

(b)

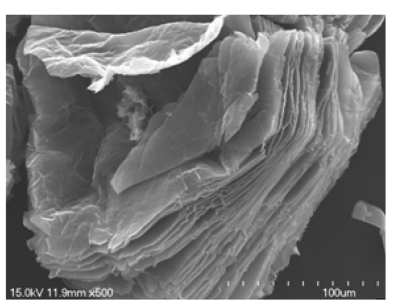

(d)

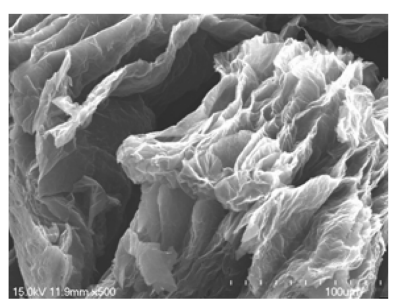

(e)

Fig. 1. SEM images of various graphite samples: (a) natural graphite, (b) A4-t30:T1000-t30, (c) A6-t30:T1000-t30, (d) A8t30:T1000-t30, and (e) A10-t30:1000-t30.

and tap-testing volume increased significantly with increasing the amount of oxidizing agent as shown in Table 1.

According to the previous works $[9,10]$, the $\mathrm{S}_{2} \mathrm{O}_{8}{ }^{2-}$ species formed by Eq. (1) and (2) causes weakening of van der Waals force between the graphite layers. As a result, the intercaltion of graphite is occurred by the introduction of $\mathrm{HSO}_{4}{ }^{-}$into the gap of graphite layers. Therefore, the chemical equation for the intercaltion of graphite by sulfuric acid can be expressed as Eq. (3).

$$
\begin{aligned}
& \mathrm{H}_{2} \mathrm{SO}_{4}+\left(\mathrm{NH}_{4}\right)_{2} \mathrm{~S}_{2} \mathrm{O}_{8} \rightarrow\left(\mathrm{NH}_{4}\right)_{2} \mathrm{SO}_{4}+\mathrm{H}_{2} \mathrm{~S}_{2} \mathrm{O}_{8} \\
& \mathrm{H}_{2} \mathrm{~S}_{2} \mathrm{O}_{8} \rightarrow 2 \mathrm{H}^{+}+\mathrm{S}_{2} \mathrm{O}_{8}^{2-} \\
& \mathrm{C}_{\mathrm{n}}+\mathrm{H}_{2} \mathrm{SO}_{4} \rightarrow \mathrm{C}_{\mathrm{n}}^{+} \mathrm{HSO}_{4}^{-}+\mathrm{H}^{+}+\mathrm{e}^{-}
\end{aligned}
$$

Table 1. Properties of various expanded graphites

\begin{tabular}{cccc}
\hline Sample & $\begin{array}{c}\text { Specific surface area } \\
{\left[\mathrm{m}^{2} / \mathrm{g}\right]}\end{array}$ & $\begin{array}{c}\text { Tap-testing volume } \\
{\left[\mathrm{cm}^{3} / \mathrm{g}\right]}\end{array}$ & $\begin{array}{c}\text { Density } \\
{\left[\mathrm{g} / \mathrm{cm}^{3}\right]}\end{array}$ \\
\hline Natural graphite & 1.35 & 1.36 & 2.26 \\
A4-t30:T1000-t30 & 7.29 & 8.43 & 0.75 \\
A6-t30:T1000-t30 & 8.21 & 12.22 & 0.76 \\
A8-t30:T1000-t30 & 11.74 & 22.71 & 0.96 \\
A10-t30:T1000-t30 & 16.23 & 24.51 & 1.04 \\
\hline
\end{tabular}




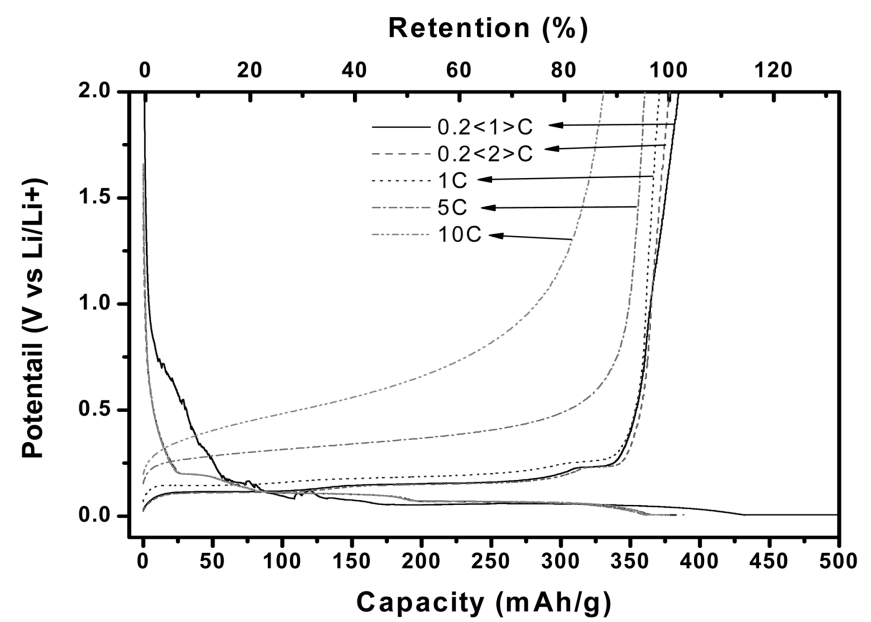

(a)

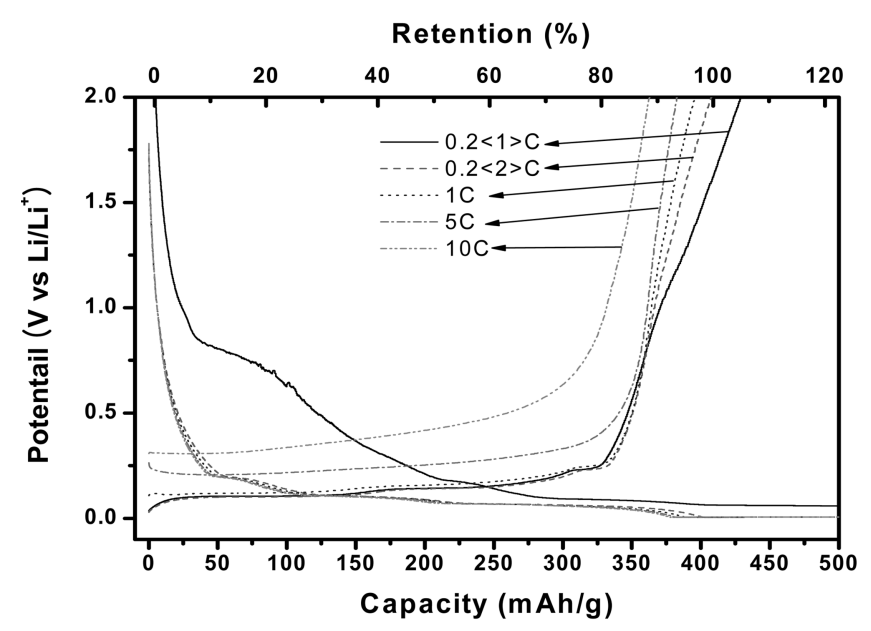

(b)

Fig. 2. Charge-discharge curves of (a) graphite and (b) expanded graphite (A8-t30:T1000-t30) as a function of C-rate.
The charge-discharge curves of natural graphite and EG (A8-t30:T1000-t30) as a function of C-rate are presented in Fig. 2. Although the expanded graphite showed the characteristics of potential plateau similar to the natural graphite, it provided the higher reversible capacity with the more declined curve to the right in the range of $0.05 \sim 2 \mathrm{~V}$ as compared with the natural graphite. Table 2 represents the charge-discharge characteristics of anodes for natural graphite and EGs with different oxidizing agent contents and heat treatment temperatures. With increasing the amount of oxidizing agent, the charge/discharge characteristics of EG increased up to $8 \mathrm{wt} . \%$ and then it decreased with the further increase. The analysis of SEM and XRD revealed that the layer structure of graphite was expanded uniformly allowing the easier intercalation/deintercalation of Li-ion up to $8 \mathrm{wt} . \%$ of oxidizing agent. However, the EG with the oxidizing agent content over $10 \mathrm{wt} . \%$ showed that the distance of graphite layer excessively widened differentiating from those with the lower oxidizing agent contents.

When the intercalated samples were heat treated in the range of $800 \sim 1200^{\circ} \mathrm{C}$ under nitrogen atmosphere, the charge/ discharge characteristics was increased until $1000^{\circ} \mathrm{C}$, but it was largely decreased with the heat treatment at $1200^{\circ} \mathrm{C}$ as shown Table 2 and 3. In this high temperature treatment, the XRD result showed the deteriorated crystallinity. It was speculated that $\mathrm{Li}$-ion intercalation/deintercalation could be inappropriate with the samples heat-treated at $1200^{\circ} \mathrm{C}$. With the increased heat treatment time, the charge/discharge characteristics was improved. It was confirmed that the sulfur content remaining in the graphite influenced on the behavior of Li-ion movement and the charge/discharge characteristic improved with the decreased sulfur content, namely, the increased heat treatment time.

After checking the electrochemical analysis of various EG anode samples prepared at the different conditions, the optimal conditions were determined as the oxidizing agent of

Table 2. Charge/discharge characteristics of natural graphite and expanded graphites with different oxidizing agent contents and heat treatment temperatures

\begin{tabular}{|c|c|c|c|c|c|c|c|}
\hline \multirow[t]{2}{*}{ Sample } & \multirow{2}{*}{$\begin{array}{c}\text { Initial reversible } \\
\text { capacity } \\
{[\mathrm{mAh} / \mathrm{g}]}\end{array}$} & \multirow{2}{*}{$\begin{array}{c}\text { Initial } \\
\text { efficiency } \\
{[\%]}\end{array}$} & \multicolumn{3}{|c|}{$\begin{array}{c}\text { Discharge rate capability } \\
{[\%]}\end{array}$} & \multicolumn{2}{|c|}{$\begin{array}{c}\text { Charge capacity } \\
{[\mathrm{mAh} / \mathrm{g}]}\end{array}$} \\
\hline & & & $1 \mathrm{C} / 0.2 \mathrm{C}$ & $5 \mathrm{C} / 0.2 \mathrm{C}$ & $10 \mathrm{C} / 0.2 \mathrm{C}$ & $5 \mathrm{C}$ & $10 \mathrm{C}$ \\
\hline Natural graphite & 360.2 & 71.8 & 98.1 & 95.2 & 87.4 & 19.4 & 10.8 \\
\hline A6-t30:T800-t30 & 397.0 & 67.3 & 95.9 & 89.9 & 81.7 & 32.7 & 18.5 \\
\hline A8-t30:T800-t30 & 393.6 & 64.4 & 97.4 & 93.0 & 87.9 & 45.6 & 23.7 \\
\hline A10-t30:T800-t30 & 344.3 & 59.7 & 95.9 & 92.1 & 71.9 & 30.2 & 18.8 \\
\hline A4-t30:T1000-t30 & 388.2 & 62.8 & 97.2 & 93.9 & 86.5 & 27.3 & 17.0 \\
\hline A6-t30:T1000-t30 & 407.1 & 54.8 & 97.4 & 92.9 & 90.0 & 50.7 & 26.2 \\
\hline A8-t30:T1000-t30 & 407.7 & 54.7 & 97.1 & 93.9 & 88.9 & 61.2 & 30.7 \\
\hline A 10 T1000-t30 & 376.5 & 61.7 & 97.3 & 91.6 & 83.3 & 38.4 & 23.8 \\
\hline A6-t30:T1200-t30 & 351.4 & 55.3 & 97.1 & 93.2 & 90.3 & 37.6 & 21.1 \\
\hline A8-t30:T1200-t30 & 397.6 & 58.2 & 97.2 & 94.5 & 91.5 & 42.6 & 24.8 \\
\hline $\mathrm{A} 10-\mathrm{t} 30: \mathrm{T} 1200-\mathrm{t} 30$ & 376.1 & 55.3 & 96.3 & 91.5 & 83.2 & 39.9 & 22.7 \\
\hline
\end{tabular}


Table 3. Charge/discharge characteristics of natural graphite and expanded graphites with different heat treatment temperature and times

\begin{tabular}{|c|c|c|c|c|c|c|c|}
\hline \multirow[t]{2}{*}{ Sample } & \multirow{2}{*}{$\begin{array}{c}\text { Initial reversible } \\
\text { capacity } \\
{[\mathrm{mAh} / \mathrm{g}]}\end{array}$} & \multirow[t]{2}{*}{$\begin{array}{c}\text { Initial efficiency } \\
{[\%]}\end{array}$} & \multicolumn{3}{|c|}{$\begin{array}{c}\text { Discharge rate capability } \\
{[\%]}\end{array}$} & \multicolumn{2}{|c|}{$\begin{array}{c}\text { Charge capacity } \\
{[\mathrm{mAh} / \mathrm{g}]}\end{array}$} \\
\hline & & & $1 \mathrm{C} / 0.2 \mathrm{C}$ & $5 \mathrm{C} / 0.2 \mathrm{C}$ & $10 \mathrm{C} / 0.2 \mathrm{C}$ & $5 \mathrm{C}$ & $10 \mathrm{C}$ \\
\hline Natural graphite & 360.2 & 71.8 & 98.1 & 95.2 & 87.4 & 19.4 & 10.8 \\
\hline A8-t30:T800-t30 & 393.6 & 64.4 & 97.4 & 93.0 & 87.9 & 45.6 & 23.7 \\
\hline A8-t30:T800-t60 & 399.5 & 71.8 & 97.0 & 91.2 & 87.1 & 35.7 & 21.9 \\
\hline A8-t30:T800-t120 & 389.1 & 61.1 & 96.8 & 93.9 & 90.4 & 52.2 & 28.7 \\
\hline A8-t30:T1000-t30 & 407.7 & 54.7 & 97.1 & 93.9 & 88.9 & 61.2 & 30.7 \\
\hline A8-t30:T1000-t60 & 400.9 & 56.6 & 96.8 & 94.8 & 89.9 & 66.1 & 29.0 \\
\hline A8-t30:T1000-t120 & 404.3 & 53.7 & 96.7 & 92.0 & 89.7 & 83.2 & 38.0 \\
\hline A8-t30:T1200-t30 & 367.1 & 57.4 & 99.3 & 97.4 & 91.1 & 42.6 & 24.8 \\
\hline A8-t30:T1200-t60 & 354.4 & 61.6 & 97.3 & 95.7 & 91.0 & 30.3 & 17.9 \\
\hline A8-t30:T1200-t120 & 362.4 & 62.6 & 97.7 & 95.4 & 90.8 & 26.2 & 15.3 \\
\hline
\end{tabular}

8 wt. $\%$ with $30 \mathrm{~min}$ 's acid treatment and further heat treatment at $1000^{\circ} \mathrm{C}$ for $120 \mathrm{~min}$. The sample (A8t30:T1000-t120) showed the improved charge/discharge characteristics such as $404.3 \mathrm{mAh} / \mathrm{g}$ of initial reversible capacity, $90.8 \%$ of discharge rate capability at $10 \mathrm{C}$-rate, and $83.2 \mathrm{mAh} / \mathrm{g}$ of charge capacity at $5 \mathrm{C}$-rate. However, this EG anode still had potential plateaus, which is not favorable for high power Li-ion secondary battery, and showed the decreased initial efficiency of $53.7 \%$ as compared with that of natural graphite $(71.8 \%)$.

\section{Conclusions}

In order to apply as the anode material for high power LIB, a series of EG with different structures were produced by changing the processing conditions such as the amount of oxidizing agent, and the heat treatment temperature and time. By using different amount of ammonium peroxodisulfate as the oxidizing agent and changing the heat treatment temperature, the behavior of intercalation compound $\left(\mathrm{H}_{2} \mathrm{SO}_{4}\right)$ and the chemical interaction in the surface, and the distance of graphite layers were influenced with the complex changes in the EG structure. With increasing the oxidizing agent, the interlayer distance between graphite layers was expanded and the more disordered structure was developed, showing the volume expansion and the increased specific surface area. The optimal conditions were determined as 8 wt.\% of the oxidizing agent with $30 \mathrm{~min}$ 's acid treatment and further heat treatment at $1000^{\circ} \mathrm{C}$ for $120 \mathrm{~min}$. The optimized anode sample showed the improved charge/ discharge characteristics such as $404.3 \mathrm{mAh} / \mathrm{g}$ of initial reversible capacity, $90.8 \%$ of discharge rate capability at
$10 \mathrm{C}$-rate, and $83.2 \mathrm{mAh} / \mathrm{g}$ of charge capacity at $5 \mathrm{C}$-rate, as compared with those for the natural graphite anode, showing the possibility of EG anode material for high power LIB.

\section{Acknowledgement}

This work was supported by Basic Science Research Program through the National Research Foundation of Korea (NRF) funded by the Ministry of Education, Science and Technology (MEST) (2010-0025033).

\section{References}

[1] Burke, A.; Kutz, M. J. Power Source 2011, 196, 524.

[2] Oh, W. C.; Kim, B. S. Bull. Korean Chem. Soc. 2000, 12, 101.

[3] Masataka, W. Mater. Sci. Eng. 2001, 3, 109.

[4] Datta, M. K.; Kumta, P. N. J. Power Source 2006, 158, 557.

[5] Kim, T. R.; Wu, J.-Y.; Hu, Q. L.; Kim, M. S. Carbon Letter 2007, 8, 335.

[6] Takei, K.; Ishihara, K.; Kumai, K.; Iwahori, T.; Miyake, K.; Nakatsu, T.; Terada, N.; Arai, N. J. Power Source 2003, 119, 887 .

[7] Adachi, K.; Tajima, H.; Hashimoto, T.; Kobayashi, K. J. Power Source 2003, 119, 897.

[8] Park, D. Y.; Park, D. Y.; Lan, Y.; Lim, Y. S.; Kim, M. S. J. Ind. Eng. Chem. 2009, 15, 588.

[9] Ko, Y. S. J. Korean Ceramic Society 1988, 25, 408.

[10] Du, X. S.; Xiao, M.; Meng, Y. Z. J. Polymer Science 2004, 42, 1972. 